\title{
気管支造影による肺癌の診断
}

\section{Diagnosis of Lung Cancer by Bronchography}

中川英二・中田肇・渡辺 勲・松浦啓一

抄録：肺癌114例の気管支造影像について, 異常所見の種類, 病巣気管支の次数, 造影技術の良 否等を総合的に判定し，気管支造影のみによる肺癌の診断能を検討した。主な所見とし ては, 閉塞像 $64.0 \%$, 狭窄像 $18.4 \%$, 異常所見のないもの $12.3 \%$ あったた、気管支の次 数による診断能は，3 次気管支までは $97 \% ， 4 ， 5$ 次では $68 \% ， 6$ 次以下では $25 \%$ であ つた。全体としては $81 \%$ が診断可能であった。診断不能例についても検討した。

\section{I はじめに}

肺癌の診断には気管支鏡による生検，経皮的 生検，気管支擦過細胞診等による確定診断が必 要であるが，気管支造影はその前段階として必 要な検査である。またそれらの確定診断が出来 ない場合，臨床診断としては最も診断的価值が 高い場合が多く，日常の一般的検查として行な われている。

肺癌における気管支造影像の所見およびその 出現頻度についてはいくつかの報告がある。今 回我々は異常所見の種類, 造影技術, 異常気管 支の次数等を総合的に判定し，その信頼度を決 め, 日常行なっている気管支造影のみによって どの程度診断が可能であるかということについ て検討した。

\section{II 対象および方法}

昭和 42 年より 49年までに当科において気管支 造影を行なった約400例のうち, 肺癌と確診され た114例をその主な対象とした.日常行なってい る気管支造影の診断能の検討が目的であるので, 一部の極端な失敗例のみ除き, 不満足な造影の

九州大学医学部放射線科学教室
場合もその対象に含めた、気管支造影の方法は 通常行なわれているメトラ氏ゾンデを用いる選 択的造影法である。

\section{III 検討結果}

\section{I. 肺癌の気管支造影所見}

肺癌114例の所見の内訳はTable 1.に示すとお りである.気管支の閉塞像を示すものが73例 64.0 \%であり，そのうち肺癌に最も特徵的な断端不 整を示すのが43例である。狭窄像は21例 $18.4 \%$ で，そのうち壁不整を示すのが18例である。圧 排所見のみが 3 例で, その他，主気管支の壁不 整 1 例, 閉塞を思わせるが造影剂の充満が十分 でなく断定出来ないものが 2 例である.気管支 造影像にて全く異常所見を認めないのが14例 12.3 \%である。この中には造影不良の為に所見が出 なかったと思われる症例も含まれている。

\section{2. 気管支の次数と診断能}

これらの所見と気管支の大きさ，造影像の良 否等を総合的に診断して，気管支造影のみによ ってどの程度診断の可能性があるかを検討した。 判定としては, ほぼ確診出来るものを(\#), 肺 癌の可能性がかなり高いと思われるものを $(+)$, 
異常所見を認めるが，圧排所見や，造影不十分 な為原発性の肺癌とは診断出来難いものを $( \pm)$, 悪性の所見が全く認められないものを $($ 一)とし た。

Table 2.に示すように（）と判定したのは 114例中75例65.8\%であり，(+)の17例14.9\%を 合わせると，約 $81 \%$ が診断可能ということにな る。

原発巣が大きい気管支にあるほど診断率が高 くなると考えられる。域気管支を 3 次として, 気管支の次数と診断の信頼度との関係をみると, 末梢になるにつれて肺癌の所見に乏しくなる。 3 次気管支までは $(+\pi)$ )が $86 \%$ であるが，4，5 次では $40 \%, 6$ 次以下では $13 \%$ である。 4 次よ り末梢になると異常所見のない頻度が高くなっ てくる.

(H)と $(+)$ を診断可能とすると, Table 3.に 示すとおり，2 次までは $100 \%, 3$ 次 $94 \% ， 4$ ， 5 次 $68 \%, 6$ 次以下は $25 \%$ が診断可能である.

な扔，(一)の判定は造影されたその次数の気 管支までは異常を認めなかったという意味であ り，原発巣はそれより末梢側にあると推定され る.

\section{3. 左右肺葉別の診断能}

左右別に診断能をみるとTable 4.の如く, 診 断可能なのは右葉 $81 \%$, 左葉76\%でほとんど差 はない。

肺葉別にみると, 右葉では診断可能なのは上 葉76\%, 下葉 $90 \%$, 左葉では上葉75\%，下葉8 0 \%で下葉の診断能がやや高いようである。これ を病巣気管支の次数でみると, Table 5.のよj に上葉気管支において末梢にみられる場合が比 較的多いので，区域気管支を 3 次とした場合， 上葉枝原発の診断が困難であるとは必ずしも云 えないようである。

中葉枝原発の症例は少ないが診断不能例が比 較的多いようである。

\section{4. 診断不能例の検討}

気管支造影では診断不能であった22例につい てその所見および原因を検討した(Table 6.).
Table 1. Bronchographic findings of lung carcinomas

\begin{tabular}{lrrrr}
\hline Finding & No. of cases & \multicolumn{1}{c}{$\%$} & \\
\hline obstruction & 73 & & 64.0 & \\
irregular & & 43 & & 37.7 \\
smooth & & 21 & & 18.4 \\
tapering & & 9 & & 7.9 \\
\hline stenosis & 21 & & 18.4 & \\
$\quad$ irregular & & 18 & & 15.8 \\
$\quad$ smooth & & 3 & & 2.6 \\
\hline compression & 3 & & 2.6 & \\
\hline others & 3 & & 2.6 & \\
\hline absence of & 14 & & 12.3 & \\
recognizable & & & & \\
abnormality & & & & \\
\hline
\end{tabular}

Table 2. Degree of abnormalities according to order of bronchus

\begin{tabular}{crrrrr}
\hline Order of bronchus & + & + & \pm & - & Total \\
\hline 1 & 9 & 0 & 0 & 0 & 9 \\
2 & 28 & 5 & 0 & 0 & 33 \\
3 & 26 & 3 & 2 & 0 & 31 \\
4 & 6 & 6 & 2 & 2 & 16 \\
5 & 4 & 1 & 1 & 3 & 9 \\
6 & 1 & 2 & 2 & 4 & 9 \\
$7 \sim$ & 1 & 0 & 1 & 5 & 7 \\
\hline Total & 75 & 17 & 8 & 14 & 114 \\
\hline
\end{tabular}

+ definite $\sim$ probable

+ possible

\pm questionable

- no evidence of malignancy

(土）と判定したのは8例であり，圧排所見のみ が 3 例, 病的に造影剂の充満が悪いと思われる が，直接所見ととれないものが 2 例，その他末 梢枝の 3 本に尖形閉塞を認め結核を疑わせた肺 胞上皮癌の症例, 辺縁がきれいな狭窄を認める もの，集束，偏位の所見を示す症例が各 1 例づ つで，いずれも異常所見を認めるが，原発性の 肺癌とは診断出来なかった症例である。

腫瘍によると思われる異常所見を全く認めな 
Table 3. Diagnostic ability according to order of bronchus

\begin{tabular}{ccc}
\hline Order of bronchus & $\begin{array}{c}\text { No. of } \\
\text { cases }\end{array}$ & $\begin{array}{c}\text { No. of } \\
\text { able to diagnose }\end{array}$ \\
\hline 1 & $9(100 \%)$ & $0(0 \%)$ \\
2 & $33(100 \%)$ & $0(0 \%)$ \\
3 & $29(94 \%)$ & $2(6 \%)$ \\
4 & $12(75 \%)$ & $4(25 \%)$ \\
5 & $5(56 \%)$ & $4(44 \%)$ \\
6 & $3(33 \%)$ & $6(67 \%)$ \\
$7 \sim$ & $1(14 \%)$ & $6(86 \%)$ \\
\hline Total & $92(81 \%)$ & $22(19 \%)$ \\
\hline
\end{tabular}

Table 4. Diagnostic ability according to lobe

\begin{tabular}{|c|c|c|c|c|c|}
\hline & obe & Diagnosis & ssible & Diagnosis & possible \\
\hline \multirow{3}{*}{ Rt. lung } & R.U.L. & $19(76 \%)$ & \multirow{3}{*}{$\begin{array}{l}51 \\
(81 \%)\end{array}$} & $6(24 \%)$ & \multirow{3}{*}{$\begin{array}{l}12 \\
(19 \%)\end{array}$} \\
\hline & R.M.L. & $4(57 \%)$ & & $3(43 \%)$ & \\
\hline & R.L.L. & $28(90 \%)$ & & $3(10 \%)$ & \\
\hline \multirow[b]{2}{*}{ Lt. lung } & L.U.L. & $24(75 \%)$ & \multirow{2}{*}{$\begin{array}{l}32 \\
(76 \%)\end{array}$} & $8(25 \%)$ & \multirow{2}{*}{$\begin{array}{l}10 \\
(24 \%)\end{array}$} \\
\hline & L.L.L. & $8(80 \%)$ & & $2(20 \%)$ & \\
\hline
\end{tabular}

Table 5. Order of abnormal bronchus according to lobe.

\begin{tabular}{lrrrrrrrr}
\hline & \multicolumn{8}{c}{ Order of bronchus } \\
\multicolumn{1}{l}{ Lobe } & 2 & 3 & 4 & 5 & 6 & $7 \sim$ Total \\
\hline \multirow{2}{*}{ Rt. } & R.U.L. & 7 & 5 & 4 & 4 & 4 & 1 & 25 \\
lung & R.M.L. & 2 & 3 & 1 & 1 & 0 & 0 & 7 \\
& R.L.L. & 14 & 10 & 4 & 1 & 0 & 2 & 31 \\
\cline { 2 - 9 } & Total & 23 & 18 & 9 & 6 & 4 & 3 & 63 \\
\hline \multirow{2}{*}{$\begin{array}{l}\text { Lt. } \\
\text { lung }\end{array}$} & L.U.L. & 10 & 8 & 3 & 2 & 5 & 4 & 32 \\
\cline { 2 - 9 } & L.L.L. & 0 & 5 & 4 & 1 & 0 & 0 & 10 \\
\hline \multicolumn{2}{c}{ Total } & 10 & 13 & 7 & 3 & 5 & 4 & 42 \\
\hline
\end{tabular}

( 9 cases of main bronchus abnormality excluded)

かったのは14例で，原発巣が造影された気管支 より末梢にあると思われる症例が12例であり， この中には病変が実在した末梢区域まで造影さ
Table 6. Evaluation of cases unable to diagnose

\begin{tabular}{cc}
\hline Contents of equivocal findings & 8 cases \\
Compression & 3 \\
Incomplete filling & 2 \\
Tapering obstruction & 1 \\
Smooth stenosis & 1 \\
Displacement & 1 \\
\hline $\begin{array}{c}\text { Causes of absence of } \\
\text { recognizable abnormalities } \\
\text { Carcinoma originating } \\
\text { in the peripheral } \\
\text { bronchus } \\
\text { Association of pleural } \\
\text { effusion } \\
\text { Association of } \\
\text { bronchiectasis }\end{array}$ \\
\hline
\end{tabular}

れていない為の診断上不十分な造影像である症 例も含まれている。他の 2 例は, 胸水による肺 の萎縮と気管支拡張が著明であった為微細な診 
断が出来なかった症例である.

\section{IV 症 例}

大きい腫瘤にもかかわらず気管支造影で肺癌 と診断出来ない症例, および気管支造影で肺癌 と診断した炎症性疾患の症例を供覧する。これ らはいづれも気管支造影診断の限界を思わせる 症例である。

\section{〔症例 1〕58才男（肺癌）}

左胸痛と咳嗽を主訴として来院. 胸部 X 線写 真にて左中野に $7 \times 5 \mathrm{~cm}$ の腫瘤状病変を認めた (Fig. 1.,2.). 辺緣整，境界鮮明で胸膜に接して いる。気管支造影で左 $\mathrm{B}_{4}, \mathrm{~B}_{5}$ は上内方に圧排さ れ, 閉塞, 狭窄等肺嵒を思わせる所見は認めな かった(Fig. 3., 4.). 肺の良性腫痬又は胸膜腫瘍 を疑って手術を行なった。組織診断は腺癌であ った、気管支等に浸潤することなく，压排性に 増殖したものと思的れる。

\section{〔症例 2〕 47才女 (肺結核症)}

咳嗽，血痰を主訴として来院. 胸部X線写真 にて右下葉無気肺と思われる㓌影を認めた( Fig. 5.).気管支造影を行なうと, 右中下葉支の不 整狭窄を認め, 下葉支へのわずかな造影剂の流 入を認めな(Fig. 6.). 肺癌の所見である.気管 支ファイバ一スコープにて右中下葉支に表面凹 凸不平の隆起による狭窄を認め, 肺癌と診断し 生検を行なった。組織診断は好酸菌を含む結核 であった。なお，気管下部の一部にもわずかな 隆起を認め，組織診により結核であった。また 喀痰からもGaffky 2 号を証明している。

この症例は気管支癌を思わせる下葉無気肺を 呈した比較的珍らしい肺結核症で, 気管支造影 所見では肺癌と診断せざるを得ない症例である。

\section{〔症例 3〕 39才 女 (肺化膿症)}

持続性の咳嗽のため某医にて胸部レ線撮影を 行ない, 右上肺野縦隔よりに腫瘤状病変を認め, 肺化膿症として各種抗生物質にて約 2 力月半治 療が行なわれたが，良くならないので当科に入 院した。入院時 (Fig. 7.)の如き腫瘤状病変を認
Fig. 1. PA view of the chest shows a large Case 1. well-defined mass in the left lung laterally.

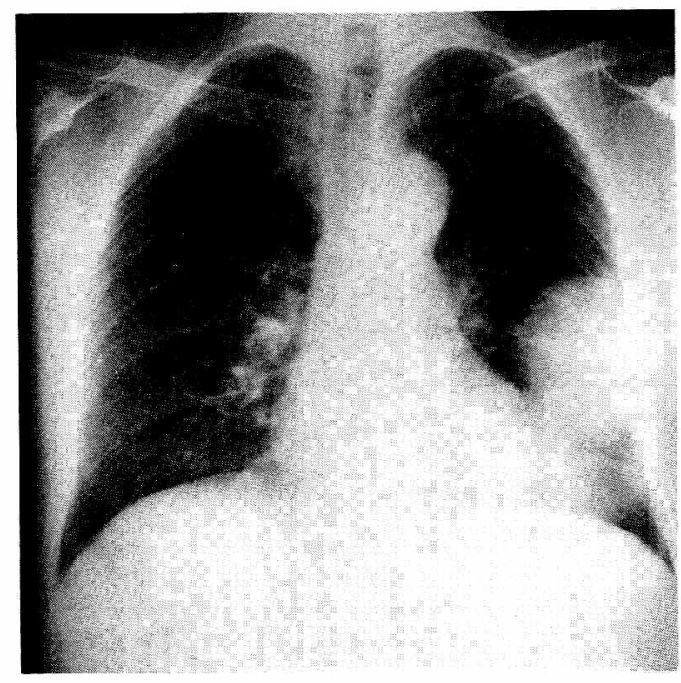

Fig. 2. The mass appears to be located in the Case 1. left upper lobe on the lateral view.

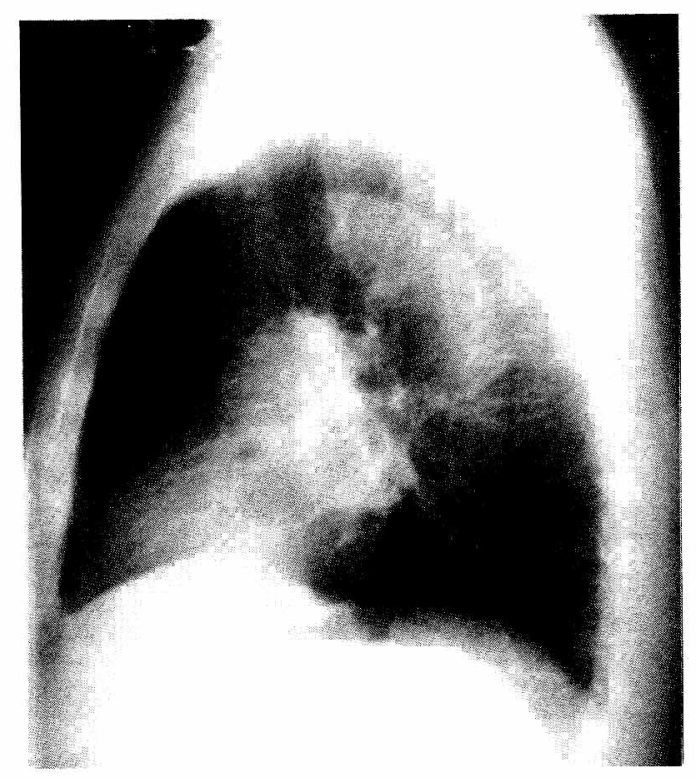

めた、気管支造影(Fig. 8.)にて右 B 2 は起始部に て断端やや不整な尖形閉塞像を示し肺癌が最も 考えられた。その後の気管支ファイバースコー プにて腫瘤の所見は認めず， $\mathrm{B}_{2}$ は同心円的な狭 窄のみで閉塞は認められなかった. 右上葉切除 
Fig. 3. PA view of the left bronchogram Case 1. shows the medial displacement of the branches of $\mathrm{B}_{4}$ and $\mathrm{B}_{5}$.

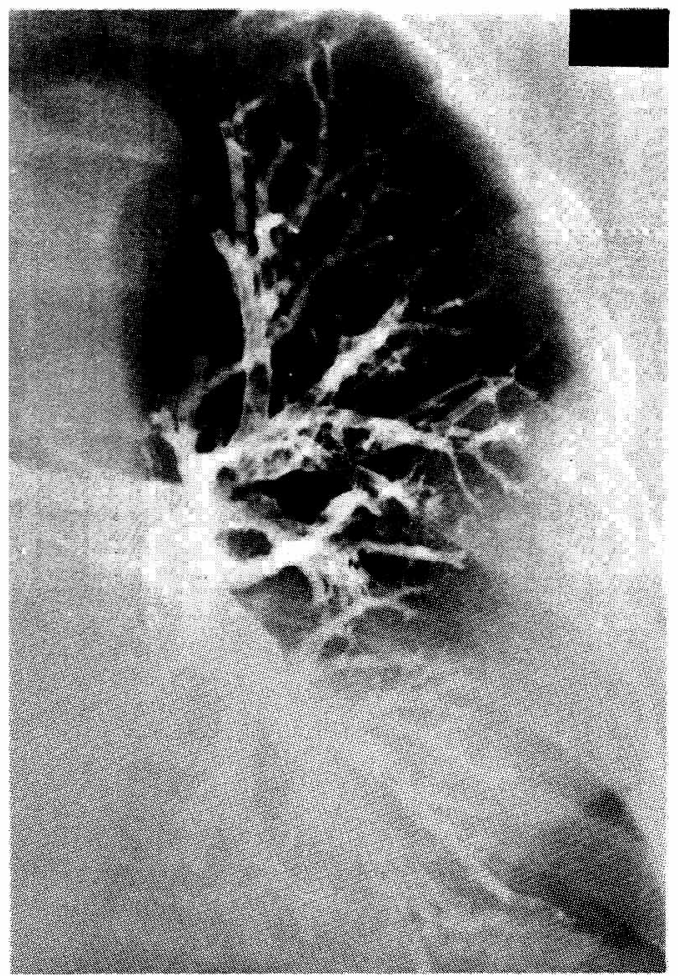

を行なった。組織診断は広範な壊死巣を含む慢 性炎症性変化のみで癌は認められなかった。

気管支造影の所見は，狭窄部が粘液等に上り 一時的に閉塞したものと思われる。

\section{$\mathrm{V}$ 考 察}

肺癌が気管支原発の腫瘍である以上，気管支 造影にて何らかの異常所見が認められるはずで 亦り，肺癌の診断㧍上び他疾患との鑑別に非常 に有効であることは今さら述べる必要寻ない。

しかし実際には患者の状態，造影技術，原発巣 の部位，X線写真の良否等により肺癌上診断出 来ない場合があることも事実である。

我々は日常行なっている気管支造影のみによ ってどの程度肺癌の診断が可能であるかという ことを検討してみた。肺癌に打ける父管支造影 像の所見の分類は池田 ${ }^{1 / 2}$, 梄林 ${ }^{6}$, 篠井 ${ }^{4 !}$, Rink $\mathrm{er}^{9)}$ 等により行なわれているが，要するに直接
Fig. 4. The branches of $B_{4} \& B_{5}$ are displaced Case 1. upward on the lateral view of the left bronchogram.

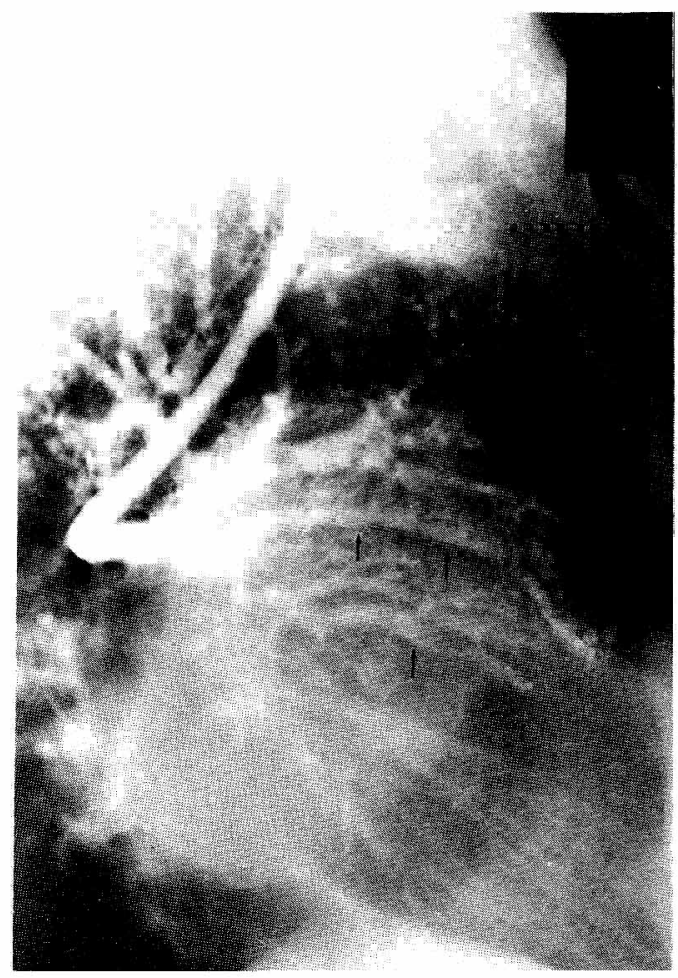

所見としては腫瘍による気管支の閉塞像か狭窄 像である。その閉塞又は狭窄の状態および周囲 気管支の所見によって他の疾患と鑑別していく わけである。しかし閉塞像を呈するものが必ず しも器質的閉塞でない場合がある。たと之ば局 所の換気状態が悪い場合，気管支分泌物が充満 している場合，技術不良の場合等あたかも閉塞 しているかの如き所見を呈することがある。し たがって同じ所見を呈していても上記の条件お よびその気管支の大きさ等により肺癌の所見と しての信頼度は違ってくる，即ち，肺癌症例に おいて気管支造影の有所見率と，診断率とはそ の意味が違ってくる。梄林 ${ }^{6)}$ は閉塞, 狭窄にお ける辺縁の状態によって肺澏の信頼度を土, +, \#の3段階に分けているが，それらに造影像の 良否も加えて判定すべきであると思われる。椾 林の昭和 41 年の報告 ${ }^{6)}$ によると診断可能例は肺 門型 $74.6 \%$ ，肺野型36.2\%であるという。しか 
Fig. 5. PA view of the chest shows the ate-

Case 2. lectasis of the right middle and lower lobes.

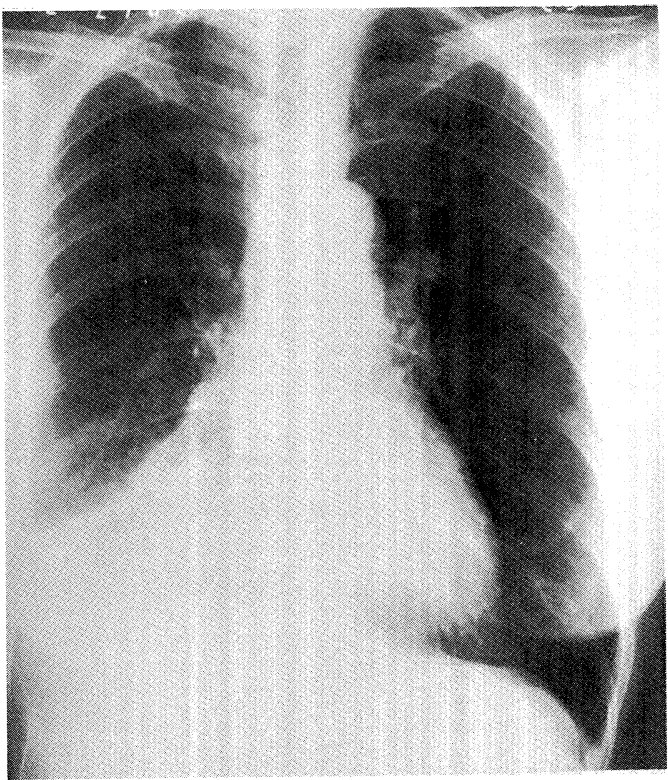

Fig. 6. Bronchogram shows the irregular steCase 2. nosis of the right intermediate bronchus.

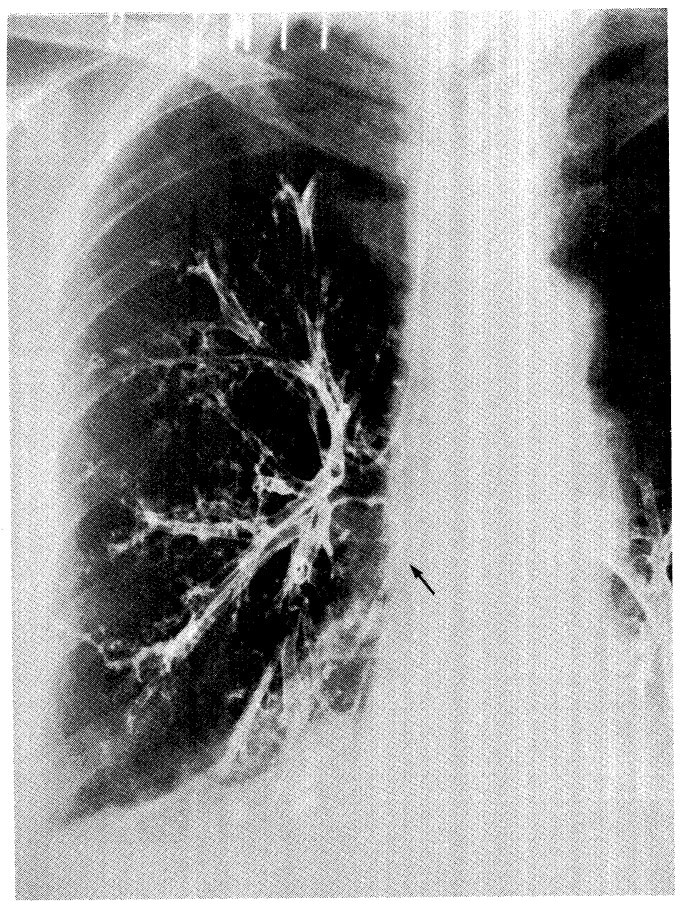

Fig. 7. There is a mass in the right upper Case 3. mediastinum on PA view of the chest.

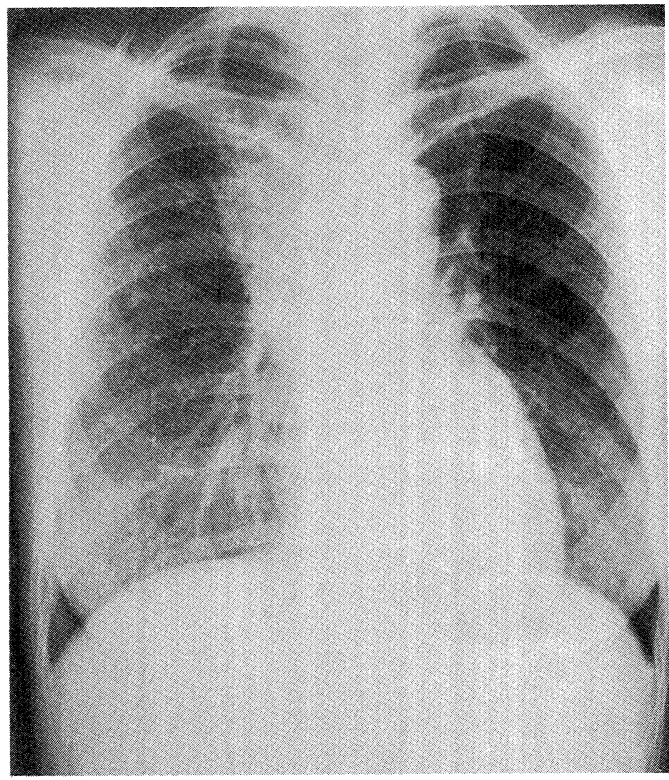

し造影技術不良のため診断不能とされたのが肺 門型で20.6\%，肺野型で44.7\%であるという. 我々は造影技術不良なものも検索症例に含めて おり，そのため末梢原発の肺癌は診断不能とさ れた症例がかなり多くなっている，5次気管支 すなわち亜々区域気管支より末梢になると診断 がかなり困難になる。特に病巣気管支領域の換 気が低下していることが多く造影剤が入りにく い状態になっている。メトラ氏ゾンデは 3 〜 4 次気管支までしか入らないので，そこで加圧し ても限度がある、楢林等は血管造影用のリモー トコントロール式のMullerカテーテルを用いて 病巣内の気管支を造影し，肺癌と他の疾患との 鑑別に有効であることを報告している7).

気管支造影による肺癌の診断能については諸 家の報告があるが，検索材料や検討方法が異な るのでそのまま比較することは適当でないと思 われる。平間 ${ }^{8)}$ は中心型および中間型 120 例全例 に閉塞像を認め，末梢型23例中 $52 \%$ に閉塞を認 め，3 cm以下の小型肺癌37例中33例（89\%）に 閉塞像を認めたと報告している。しかし, 非癌 性肺疾患39例中30例（77\%）に閉塞像を認めて 
Fig. 8. Lateral view of the right bronchogram

Case 3. shows the irregular obstruction of the origin of $\mathrm{B}_{2}$.

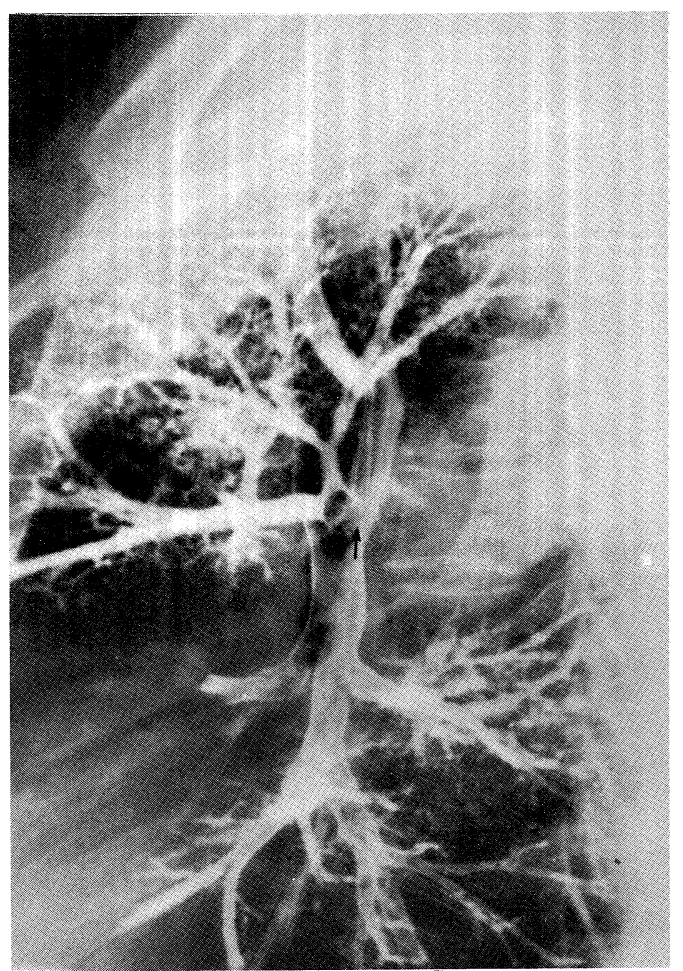

おり，閉塞像のみによる鑑別診断は困難である と述べている。池田 ${ }^{1) 2)}$ は肺癌279例の気管支造 影診断は93.2\%であったが，末梢型の場合気管 支の変形像のみで診断することは困難なことが 多いことを指摘している。すなわち，病巣の部 位や，周囲気管支を含めた拡張，分岐欠如，集 束像等の間接所見が特に結核等との鑑別に必要 であることを強調している。馬屋原 ${ }^{3)}$ は肺野型 を主とした症例の気管支造影による診断能は約 70\%であったと報告している。梄林 ${ }^{6)}$ は肺門型 $74.6 \%$, 肺野型 $36.2 \%$ が診断可能であるといい, その後の微細選択気管支造影では肺癌の全症例 に異常所見を見出し得るようになったという． Wilt ${ }^{10)}$ は肺癌236例中 $89 \%$ に閉塞を認めている。

Rinker ${ }^{9)}$ は肺癌に特徵的な $6 つ の$ 所見を示し， それらの所見を認める99例のうち95\%が肺癌で あり，肺癌で異常所見を示さなかったのは 4 例 であったという。篠原 ${ }^{5}$ はRinkerの分類により
検討している．肺癌141例のうち120例（85\%） がRinkerの病型に分類可能であったといい，残 り21例にも肺癌としての所見がみられたことを 述べている。このRinker らの6 所見のすべてが 必らずしも肺癌に特徵的であるかどうかにはや や疑問がある。

症例で供覧した如く，一見肺癌の所見を呈す る非癌性疾患も珍らしくなく，肺癌の診断には 慎重でなければならない。特に造影技術の良否 がその診断を不能にし，また誤診の原因となる ことも比較的多いことを認識する必要があると 思われる。

\section{VI まとめ}

肺癌114例の気管支造影所見を分析し, 気管支 造影による肺癌の診断能について検討した。

異常所見の種類, 気管支の次数抒よび造影技 術, 写真の良否等を総合的に判定し, その診断 能は $81 \%$ であった。6 次気管支より末梢になる と診断出来ない症例が多くなってくる.

主な所見としては, 閉塞像 $64.0 \%$, 狭窄像 18.4 \%で，異常所見のないものが12.3\%であった。

診断出来なかった症例の所見とその原因につ いても検討した。 
文 献

1）池田茂人, 坪井栄孝他：胸部外科, $21: 710$ 431, 1966. 719, 1968.

2) 池田茂人, 久留 勝, 石川七郎監修: 肺癌図譜,

7）楢林和之, 高田佳木他：臨放，15：795 807, 1970. 186 193, 中山書店, 1968.

3）馬屋原晟：医療， $27: 516 \sim 519,1973$.

8) 平間 仁: 抗酸菌病研究雑誌, $18: 326 \sim 346$, 1966.

4）篠井金吾, 早田義博他：癌の臨床, 別冊, 247 255, 1965.

9) Rinker, C. T., Garrotto, L.J., Lee, K.R. and Templeton, A.W. : Am. J. Roentgenol. 104 : 802-807, 1968.

5）篠原慎治, 曽根博文他：臨放，16：724～733, 1971.

6）楢林和之, 林 新樹他：診断と治療, 54 ：422

10) Wilt, K. E., Andrews, N.C., et al. : Dis. Chest, $35:$ 517-523, 1959.

\title{
Diagnosis of lung cancer by bronchography
}

Eiji Nakagawa, M.D. Hajime Nakata, M.D.

Isao Watanabe, M.D. Keiichi Matsuura, M.D.

\author{
Department of Radiology, Kyushu University School of \\ Medicine, Fukuoka, Japan. \\ (Directer: Prof. Keiichi Matsuura)
}

Bronchograms of 114 cases of lung cancers were reviewed. Findings on bronchograms were evaluated in relation to the order of the abnormal bronchus and the adequateness of the technique. Sixty Four $\%$ of the cases showed obstruction and $18.4 \%$ had stenosis. There were $12.3 \%$ without recognizable abnormality. As for the diagnostic ability according to the order of bronchus, $97 \%$ of the cases originating up to $3 \mathrm{rd}$ order bronchus and $68 \%$ of the lesions in 4 th and 5 th order bronchus were diagnosable. When located in the 6 th order bronchus or more peripherally, the diagnosis was possible only in $25 \%$ of cases.

In total the diagnosis with bronchography was possible in $81 \%$ of the cases. In $19 \%$ it was not possible due to the presence of equivocal findings alone or the absence of recognizable abnormality. 